\title{
Simulasi CFD Aliran Stratified Air-Udara pada Pipa Horisontal
}

\author{
(CFD Simulation of Air-Water on Stratified Flow Pattern in Horizontal Pipes)
}

\author{
SUKAMTA, THOHARUdiN, DEDY MEILANTO NUGROHO
}

\begin{abstract}
Two-phase flow can be found in industries, such as petroleum, electricity generation. In geothermal power plants, two-phase flow occurs from a mixture of water and steam which should be avoided in the piping system because it can cause equipment damage in the operating system. Therefore, an operator and engineer need a knowledge of flow patterns, phenomena and characteristics of the two-phase flow. One of the methods to predict the flow pattern is udlsing the Computational Fluid Dynamic (CFD). This CFD simulation was modeled using Ansys Fluent 15.0 software to determine the changes of Stratified flow characteristics. The model used is Volume of Fluid (VOF). The fluid type is water and air. The variation of superficial water velocity $J_{L}$ of $0.025 \mathrm{~m} / \mathrm{s}-0.1 \mathrm{~m} / \mathrm{s}$ while the superficial air velocity $\left(\mathrm{J}_{\mathrm{G}}\right)$ of $0.05 \mathrm{~m} / \mathrm{s}-1 \mathrm{~m} / \mathrm{s}$. The pipe used is an acrylic of $19 \mathrm{~mm}$ diameter and length of $1000 \mathrm{~mm}$. The simulation results show that: (1). Stratified flow occurred for the low velocity of the liquid and gas phases. It was shown by the water and air are clearly separated. (2). Flow patterns are not stable, but it can change depending on the superficial velocity of gas and water. (3). The larger of $\mathbf{J}_{\mathrm{G}}$ causes the wave height because of Bernoulli's effect so that it will make the stratified wavy or ripple flow pattern. (4). The frequency of stratified-wavy and ripple waves will tend to decrease when the $\mathrm{J}_{\mathrm{L}}$ increases, while the effect of $\mathrm{J}_{\mathrm{G}}$ is insignificant. Furthermore, it can be concluded that the speed of gas must be regulated so as not too large to the speed of water.
\end{abstract}

Keywords : Two-phase flow, stratified, CFD, flow pattern

\section{PENDAHULUAN}

Aliran dua fase merupakan fenomena alam yang sangat sering dijumpai dalam kehidupan sehari-hari. Pada pembuatan kopi, salju, aliran darah, alat-alat rumah tangga (misalnya : air conditioner, kulkas, dan lain-lain), serta banyak digunakan dalam kegiatan industri contohnya, dalam perpipaan untuk mengalirkan produk yang berbentuk fluida maupun perpipaan penukar panas (heat exchanger).

Ada beberapa pola aliran yang terjadi pada aliran dua fase, salah satunya adalah aliran strata licin (stratified). Aliran stratified, karakter aliran cairan bergerak di bawah sedangkan gas berada di atas pipa, terbentuk dengan debit gas dan cairan yang rendah.

Penelitian mengenai fluktuasi tekanan dan tegangan geser antar muka pada aliran stratified air-udara pada pipa horisontal pernah dilakukan oleh Gunawan, dkk (2015). Metodologi penelitian visualisasi dengan pengukuran beda tekanan dan kondisi adiabatic. Variabel pada penelitian ini meliputi kecepatan superfisial air $\left(\mathrm{J}_{\mathrm{L}}\right)$ dari $0,025 \mathrm{~m} / \mathrm{s}$ sampai $0,1 \mathrm{~m} / \mathrm{s}$ dan kecepatan superfisial udara $\left(\mathrm{J}_{\mathrm{G}}\right) \quad 0,94 \mathrm{~m} / \mathrm{s}$ sampai $12 \mathrm{~m} / \mathrm{s}$. Hasil penelitian menunjukkan bahwa pola aliran stratified yang meliputi stratified smooth, stratified wavy + ripple, stratified wavy + roll dan pseudo-slug telah berhasil diidentifikasi baik secara visual dan sinyal tekanan.

Santoso, dkk (2012) juga pernah meneliti fluktuasi beda tekanan dari aliran slug air-udara pada aliran dua fase searah pipa horisontal dengan panjang pipa $10 \mathrm{~m}$ dan diameter dalam $24 \mathrm{~mm}$. Perubahan kecepatan superfisial udara dan kecepatan superfisial air dapat dibedakan dengan jelas menggunakan analisis statistik, PDF, autokorelasi dan PSD.

Penelitian terkait pola aliran fluida tipe single dan multiphase terus berkembang. Mazumder (2012) melakukan analisis aliran single dan multiphase pada pipa tipe elbow. Pola karakteristik aliran yang diamati ada pada 6 titik berbeda dengan memberikan variasi 3 jenis 
kecepatan udara dan 3 jenis kecepatan air. Hasilnya profil tekanan dan kecepatan pada 6 titik menunjukkan peningkatan pada tekanan di geometri elbow dengan penurunan tekanan pada sisi outlet karena fluida yang meninggalkan elbow. Pola penurunan tekanan yang diamati akan serupa untuk aliran singlephase dan multiphase.

Pola aliran dua fasa uap-kondensat berdasarkan pengukuran beda tekanan pada pipa horisontal juga pernah diteliti oleh Sukamta, dkk (2010). Bahan yang digunakan pipa anulus bagian dalam dari bahan tembaga berdiameter $17 \mathrm{~mm}$ dengan panjang 1,6 m, sedangkan pipa anulus bagian luar adalah pipa besi berdiameter 4 inchi. Hasilnya Pola aliran yang teridentifikasi pada aliran dua fasa air-uap air (kondensat) dari hasil kondensasi uap pada pipa horisontal ini meliputi pola aliran stratified, wavy, plug, preslug, dan slug.

Korawan, (2015) meneliti pola aliran dua fase (air-udara) pada pipa horisontal dengan variasi kecepatan superfisial air. Bahan penelitian menggunakan pipa acrylic dengan diameter dalam $36 \mathrm{~mm}$ dan panjang $2000 \mathrm{~mm}$. Metode yang dipakai dalam penelitian ini adalah visualisasi dengan variasi kecepatan superfisial air. Air digunakan sebagai fluida cair dan udara sebagai fluida gas. Pola aliran yang teramati adalah bubble flow, slug flow dan stratified flow. Semakin besar nilai Usl mengakibatkan semakin panjang bubble region yang terjadi.

Penelitian aliran dua fase dengan metode visualisasi sudah pernah dilakukan oleh Santoso, dkk (2011). Namun pola aliran yang diteliti adalah pola aliran kantung (plug) dan sumbat likuid (slug). Dalam penelitian ini pipa yang digunakan adalah pipa yang terbuat dari acrylic yang mempunyai diameter dalam 24 $\mathrm{mm}$ dengan panjang $10 \mathrm{~m}$. Fluida yang digunakan adalah air dan udara. Hasilnya pola aliran slug dan kecepatan gelembung dapat diamati secara visualisasi dengan jelas.

Abbasi, dkk (2014) pernah melakukan simulasi aliran dan transfer panas dari nano fluid 2 fase (aliran stratified regime). Bahan nanopartikel tembaga, emas, titanium oxside, digunakan pada penelitian ini untuk menghasilkan nanofluid dengan waterasthebaseluid dalam pipa panjang $1 \mathrm{~m}$ berdiameter $0.0512 \mathrm{~m}$. Metode yang digunakan dalam penelitian ini menggunakan variasi cairan terhadap panjang pipa. Hasil dari penelitian dua fase perpindahan posisi terendah panas menurun sepanjang kualitas uap meningkat.

Terzuoli, dkk (2008) melakukan penelitian kode validasi data eksperimen $C F D$ terhadap aliran stratified air-udara. Pada aliran inlet menggunakan variasi kecepatan superfisial air dan udara. Penelitian dilakukan menggunakan aplikasi Ansys CFX dan Fluent 10.0. Dengan penampang persegi panjang dengan tinggi 0,1 $\mathrm{m}$, lebar $0,2 \mathrm{~m}$ dan panjang $13 \mathrm{~m}$. Hasilnya adalah data eksperimen dan simulasi telah dilakukan dengan CFD melalui aplikasi NEPTUNE CFD V1.0.6, FLUENT 6.1, dan CFX 10.0 dimodelkan dengan Gambit 1.0 dan ANSYS ICEM 10.0 software.

Desamala, dkk (2013) pernah meneliti Simulasi $C F D$ dan validasi pola aliran bounderies transisi aliran dua fasa air-minyak melalui pipa horisontal. Pipa yang digunakan pipa horisontal dengan diameter dan panjang masing-masing $0,025 \mathrm{~m}$ dan 7,16 $\mathrm{m}$. Metode VOF digunakan dalam penelitian ini, pengaruh tegangan permukaan digunakan untuk memprediksi terjadinya pola aliran. Aplikasi yang digunakan Ansys CFD dan Fluent. Hasil penelitian untuk memprediksi pola aliran pada sistem 47.037 sel didapatkan untuk simulasi transisi gelombang dikelompokkan ke aliran campuran bertingkat.

Hudaya, dkk (2013), melakukan penelitian penentuan sub-sub daerah aliran stratified udara-air pada pipa horisontal (dia. dalam pipa $26,0 \mathrm{~mm}$ dan total panjang seksi uji 9,5 m) menggunakan Constant Electric Current Method (CECM). Dalam penelitian ini digunakan sensor CECM sebanyak 3 buah dengan jarak aksial antar sensor $215 \mathrm{~mm}$. Hasil penelitian ini menunjukkan bahwa karakteristik gelombang antar muka yang dihasilkan dari pemrosesan sinyal CECM dan studi visual dapat digunakan untuk menentukan sub-sub daerah aliran stratified. Sekarang ini, telah ditemukan sebuah metode berbasis sistem komputer yang mampu melakukan simulasi dan analisa terhadap aliran suatu fluida. Dengan adanya metode tersebut maka kemungkinan terburuk dari fenomena fluktuasi tekanan dapat dihindari, karena dilakukan simulasi dan kemudian hasilnya dapat dianalisa. Hasil dari simulasi tersebut akan menampilkan pola yang akan terjadi dalam sistem aliran fluida yang direncanakan.

Computational Fluid Dynamic (CFD) sangat cocok digunakan untuk melakukan analisa terhadap sebuah sistem yang rumit dan sulit 
dipecahkan dengan perhitungan manual dan dapat memberikan kekuatan untuk mensimulasikan aliran fluida, perpindahan massa, benda-benda bergerak, aliran multifasa, reaksi kimia, dan sistem akustik hanya dengan pemodelan di computer. Dengan menggunakan software ini akan tampak bentuk virtual prototype dari sistem yang digunakan sesuai dengan keadaan di lapangan. $C F D$ akan memberikan data-data, dan gambar-gambar, atau kurva-kurva yang menunjukkan prediksi dari performansi keandalan sistem tersebut. Dengan kelebihannya tersebut CFD sering digunakan untuk melakukan analisa terhadap suatu pola sebuah sistem. Adapun software $C F D$ yang sering digunakan adalah Fluent, Comsol, Solid Flow dan lainnya.

Dalam penelitian ini akan dilakukan analisa terhadap suatu aliran fluida dengan aliran searah pada pipa horizontal menggunakan software CFD Ansys Fluent 15.0 untuk memprediksi pola aliran yang terjadi. Maka perlu disajikan beberapa persamaan yang menjadi dasar analisis, yaitu Kecepatan Superficial gas $\mathrm{J}_{\mathrm{G}}=\frac{\mathrm{Q}_{\mathrm{G}}}{\mathrm{A}}$ (1) dan Kecepatan superficial liquid $\mathrm{J}_{\mathrm{L}}=\frac{\mathrm{Q}_{\mathrm{L}}}{\mathrm{A}}$ (2) dengan $\mathrm{J}_{\mathrm{G}}$ Kecepatan superficial gas $(\mathrm{m} / \mathrm{s}) ; \mathrm{J}_{\mathrm{L}}$ Kecepatan superficial liquid $(\mathrm{m} / \mathrm{s}) ; \mathrm{Q}_{\mathrm{G}}$ Laju aliran gas dalam pipa $\left(\mathrm{m}^{3} / \mathrm{s}\right) ; \mathrm{Q}_{\mathrm{G}}$ Laju aliran liquid dalam pipa $\left(\mathrm{m}^{3} / \mathrm{s}\right)$; A Luas penampang pipa $\left(\mathrm{m}^{2}\right)$. Di dalam prakteknya banyak peneliti menggunakan model Mertinelli untuk menunjukan penggali dua fase $\left(\Phi_{1}{ }^{2}\right)$ :

$$
\begin{gathered}
\Phi_{1}^{2}=\frac{\Delta P_{T P}^{F}}{\Delta P_{L}^{F}}=1+\frac{C}{X n}+\frac{1}{X n^{2}} \\
\mathrm{X}_{\mathrm{n}}=\left[\frac{1-\mathrm{x}}{\mathrm{x}}\right]^{0.9}\left[\frac{\rho_{G}}{\rho_{L}}\right]^{0.5}\left[\frac{\mu_{L}}{\mu_{G}}\right]^{0.1}
\end{gathered}
$$

Sedangkan fraksi hampa aliran terpisah dihitung dengan persamaan

$$
\alpha_{1} \frac{1}{1+\left[\frac{u_{g}(1-x) \rho_{g}}{u_{1} x \rho_{j}}\right]}
$$

dengan $\mathrm{x}=$ Kualitas uap; $\mathrm{D}=$ Diameter pipa (m); $\mathrm{f}=$ koefisien gesek; $\mathrm{G}=$ Fluks massa aliran $(\mathrm{kg} / \mathrm{m} 2 \mathrm{~s}) ; 1$ =Liquid; $\mathrm{g}=\mathrm{Gas} ; \mathrm{P}=$ Penurunan tekanan; TP $=$ Two Phase; $\rho=$ Massa jenis $(\mathrm{kg} /$ $\mathrm{m} 3) ; \mu=$ Viskositas dinamik $(\mathrm{N} / \mathrm{m} 2 \mathrm{~s}) ; \alpha=$ Fraksi hampa; $\Phi=$ Pengali dua fase $\rho=$ Selisih atau beda.

\section{Metode Penelitian}

Secara umum proses simulasi $C F D$ dibagi menjadi 3 yaitu Pre-Processing, Processing dan Post-Processing seperti ditunjukkan pada gambar 1.

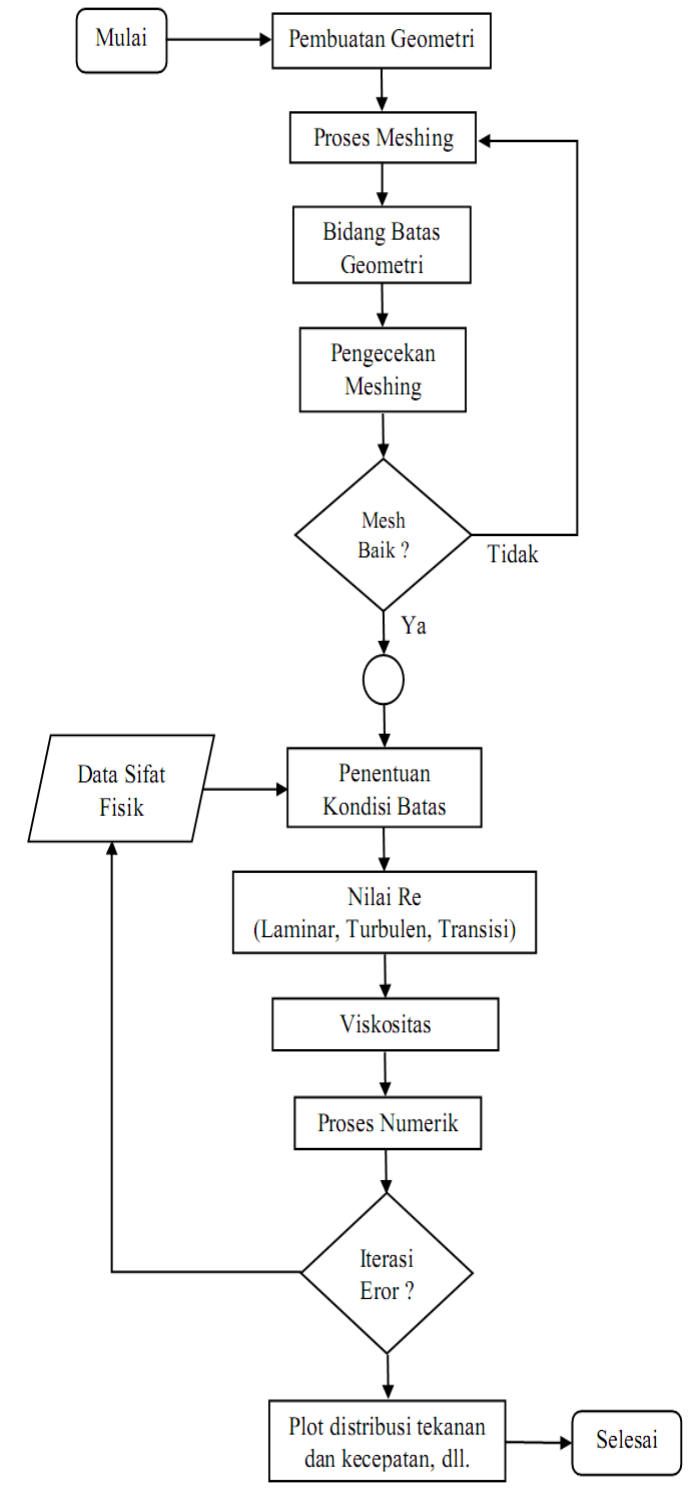

GAmbar 1. Diagram Alir Proses Simulasi Menggunakan Ansys Fluent 15.0

Pre-Processing adalah tahap awal dalam simulasi CFD yang perlu dilakukan, seperti membuat geometri, meshing, mendifinisikan bidang batas pada geometri dan melakukan pengecekan mesh. Sednagkan Procesing meliputi penentuan kondisi batas, proses numerik, dan iterasi. Post-Processing meliputi plot distribusi tekanan, temperature, volume fraction, dan sebagainya.

Sketsa geometri yang digunakan dalam simulasi ini adalah pipa berdiameter $19 \mathrm{~mm}$ dan panjang 
pipa $1000 \mathrm{~mm}$ dengan menggunakan 2 inlet yaitu inlet air dan inlet udara serta 1 outlet seperti gambar 2. Agar fluida air dan udara dapat bercampur dan menghasilkan sebuah pola aliran yang dikehendaki.

Setelah geometri dibuat, perlu dilakukan proses meshing (membagi volume menjadi bagianbagian kecil) agar dapat dianalisis pada program $C F D$ seperti ditunjukkan gambar 3. Ukuran mesh yang terdapat pada suatu obyek akan mempengaruhi ketelitian dan daya komputasi analisis $C F D$. Semakin kecil/halus mesh yang dibuat, maka hasil yang didapatkan akan semakin teliti, namun dibutuhkan daya komputasi yang makin besar pula.

Pada penelitian ini mesh yang digunakan jenis triangle atau tidak terstruktur. Setelah itu tiap pipa diberi nama sesuai dengan fungsi dan bagian pipa.

Penelitian ini menggunakan metode simulasi Computational Fluid Dinamic (CFD) dengan software Ansys Fluent 15.0. Dengan memilih model Multiphase jenis VOF (Volume of
Fluid), untuk mengetahui pengaruh tegangan permukaan dan digunakan untuk memprediksi terjadinya pola aliran. Untuk viscous disetting menggunakan k-epsilon dengan model realizable. Pada kasus simulasi ini, Realizable k-epsilon dipilih karena memiliki tingkat akurasi yang lebih baik dibanding metode standard k-epsilon ataupun $R N G$ k-epsilon. Material yang digunakan adalah acrylic flexyglass sedangkan untuk fluida menggunakan water-liquid dan air. Simulasi ini menggunakan skema SIMPLE, persamaan yang digunakan untuk aliran transient atau untuk mesh yang mengandung cells dengan skewness yang lebih tinggi dari rata-rata. Metode ini didasarkan pada tingkatan yang lebih tinggi dari hubungan pendekatan antara faktor koreksi tekanan dan kecepatan. Dalam proses iterasi tidak menunggu konvergensi dikarenakan ini jenis aliran transient. Dengan tingkat akurasi time step 0,001. Variasi kecepatan superfisial udara adalah $\mathrm{J}_{\mathrm{G}}=0,05 \mathrm{~m} / \mathrm{s}$ sampai dengan 1 $\mathrm{m} / \mathrm{s}$ dan $\mathrm{J}_{\mathrm{L}=} 0,025 \mathrm{~m} / \mathrm{s}$ sampai dengan $0,1 \mathrm{~m} / \mathrm{s}$.

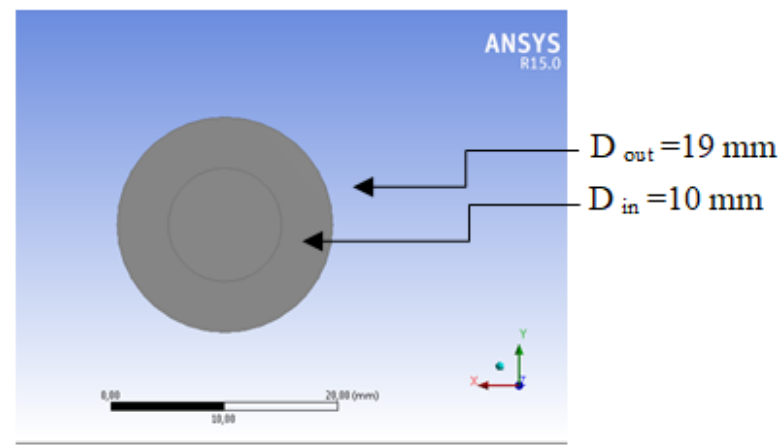

GAMBAR 2. Pipa Tampak Depan

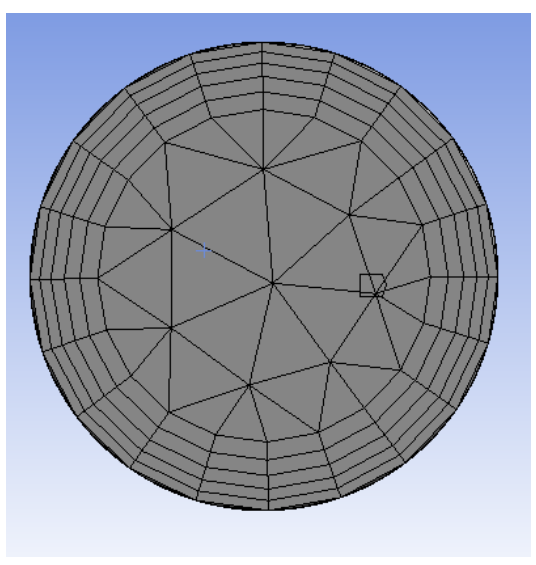

GAMBAR 3. Hasil Meshing (Outlet) 


\section{HASIL DAN PEMBAHASAN}

Hasil dari simulasi pola aliran pada pipa horizontal menggunakan software Ansys Fluent 15.0 dibedakan dengan 4 variasi kecepatan superfisial air $\left(\mathrm{J}_{\mathrm{L}}\right)$ yaitu $0,025 \mathrm{~m} / \mathrm{s}, 0,05 \mathrm{~m} / \mathrm{s}$, $0,075 \mathrm{~m} / \mathrm{s}, 0,1 \mathrm{~m} / \mathrm{s}$ dan 4 variasi kecepatan superfisial udara $\left(\mathrm{J}_{\mathrm{G}}\right)$ yaitu $0,05 \mathrm{~m} / \mathrm{s}, 0,1 \mathrm{~m} / \mathrm{s}$, $0,5 \mathrm{~m} / \mathrm{s}, 1 \mathrm{~m} / \mathrm{s}$. Proses pengambilan data diambil 6 kali dengan waktu $0,3 \mathrm{~s}, 0,6 \mathrm{~s}, 0,9 \mathrm{~s}$, $1,2 \mathrm{~s}, \quad 1,5 \mathrm{~s}$, dan 1,8 s. Hasil simulasi menampilkan pengaruh kecepatan udara dan pengaruh waktu antara nilai $\mathrm{J}_{\mathrm{G}}$ dan $\mathrm{J}_{\mathrm{L}}$. Arah aliran fluida menuju sumbu z. Berikut adalah hasil dari simulasi aliran searah pada pipa horisontal.

\section{Pengaruh Kecepatan Superfisial Udara $\left(J_{G}\right)$ Terhadap $J_{L}=0,025 \mathrm{~m} / \mathrm{s}$}

Variasi pertama adalah menggunakan $\mathrm{J}_{\mathrm{G}}=0,05$ $\mathrm{m} / \mathrm{s}, 0,1 \mathrm{~m} / \mathrm{s}, 0,5 \mathrm{~m} / \mathrm{s}$ dan $1 \mathrm{~m} / \mathrm{s}$ terhadap $\mathrm{J}_{\mathrm{L}}=$ $0,025 \mathrm{~m} / \mathrm{s}$, menghasilkan simulasi pola aliran terlihat pada Gambar 4.

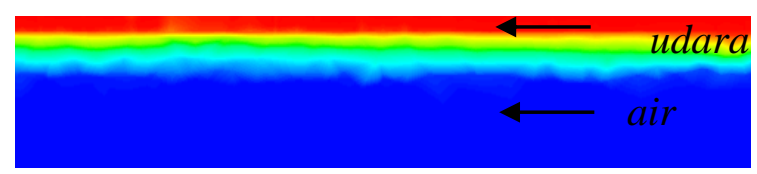

a) Pola aliran air-udara dengan $\mathrm{J}_{\mathrm{G}}=0,05$ $\mathrm{m} / \mathrm{s}$ dan $\mathrm{J}_{\mathrm{L}}=0,025 \mathrm{~m} / \mathrm{s}$

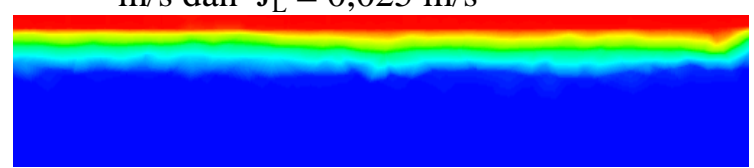

b) Pola aliran air-udara dengan $\mathrm{J}_{\mathrm{G}}=0,1$ $\mathrm{m} / \mathrm{s}$ dan $\mathrm{J}_{\mathrm{L}}=0,025 \mathrm{~m} / \mathrm{s}$

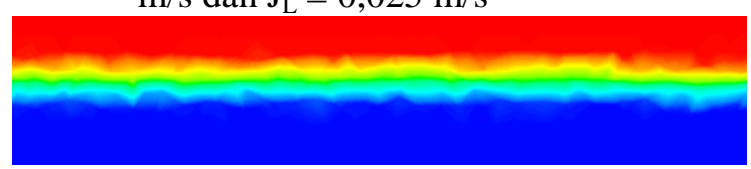

c) Pola aliran air-udara dengan $\mathrm{J}_{\mathrm{G}}=0,5$ $\mathrm{m} / \mathrm{s}$ dan $\mathrm{J}_{\mathrm{L}}=0,025 \mathrm{~m} / \mathrm{s}$

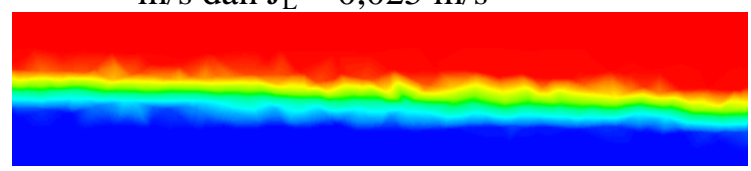

d) Pola aliran air-udara dengan $J_{G}=1 \mathrm{~m} / \mathrm{s}$ dan $\mathrm{J}_{\mathrm{L}}=0,025 \mathrm{~m} / \mathrm{s}$

GAMBAR 4. Hasil simulasi pola aliran terhadap pengaruh kecepatan superfisial udara $\left(\mathrm{J}_{\mathrm{G}}\right)$ terhadap $\mathrm{J}_{\mathrm{L}}=0,025 \mathrm{~m} / \mathrm{s}$

Simulasi dengan $\mathrm{J}_{\mathrm{L}}=0,025 \mathrm{~m} / \mathrm{s}$ menunjukkan bahwa telah terjadi sebuah pola aliran stratified, seperti pada gambar 4. yang ditandai udara berada di atas pipa sedangkan air berada di bawah pipa. Persentase antara air dan udara begitu jelas terlihat ketika kecepatan udara rendah dengan $J_{G}=0,05 \mathrm{~m} / \mathrm{s}$ pola yang dihasilkan udara berada di atas permukaan pipa dikarenakan amplitudo udara yang masuk bertekanan rendah. Sedangkan ketika kecepatan $\mathrm{J}_{\mathrm{G}}$ dinaikkan mencapai $1 \mathrm{~m} / \mathrm{s}$ pola yang dihasilkan udara dan air berada di tengahtengah pipa. Hal ini disebabkan oleh amplitudo udara yang masuk lebih besar sehingga tekanan yang dihasilkan lebih besar pula ketika memasuki pipa.

\section{Pengaruh Waktu Terhadap Kecepatan} Superfisial Udara $\left(J_{G}\right)$ Dengan $J_{L}=0,025 \mathrm{~m} / \mathrm{s}$

Variasi pertama adalah menggunakan $\mathrm{JG}=0,05$ $\mathrm{m} / \mathrm{s}$ dan $\mathrm{JL}=0,025 \mathrm{~m} / \mathrm{s}$, dengan waktu yang berbeda menghasilkan simulasi pola aliran terlihat pada gambar 5 .

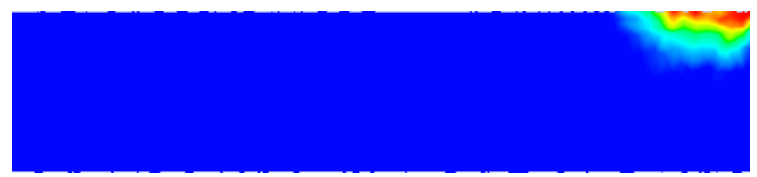

a) Pola aliran air-udara dengan $\mathrm{J}_{\mathrm{G}}=0,05$ $\mathrm{m} / \mathrm{s}$ pada detik ke 0,3

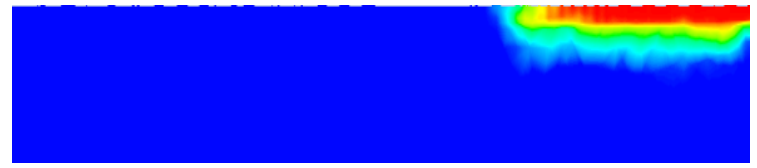

b) Pola aliran air-udara dengan $\mathrm{J}_{\mathrm{G}}=0,05$ $\mathrm{m} / \mathrm{s}$ pada detik ke 0,6

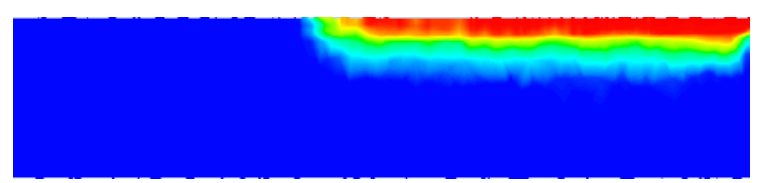

c) Pola aliran air-udara dengan $\mathrm{J}_{\mathrm{G}}=0,05$ $\mathrm{m} / \mathrm{s}$ pada detik ke 0,9

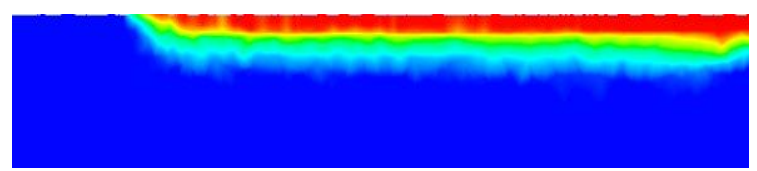

d) Pola aliran air-udara dengan $J_{G}=0,05$ $\mathrm{m} / \mathrm{s}$ pada detik ke 1,2

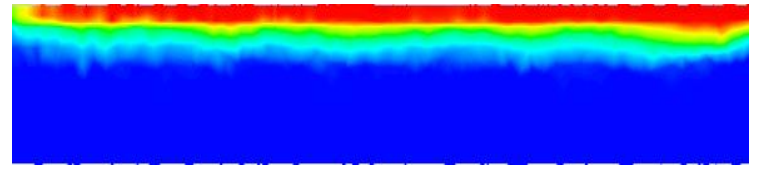

e) Pola aliran air-udara dengan $\mathrm{J}_{\mathrm{G}}=0,05$ $\mathrm{m} / \mathrm{s}$ pada detik ke 1,5

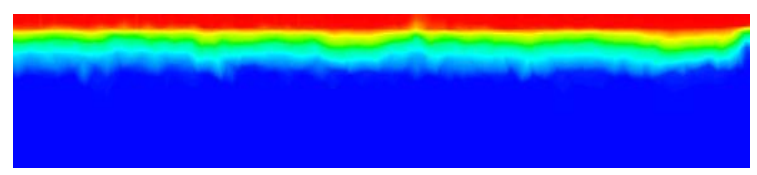

f) Pola aliran air-udara dengan $J_{G}=0,05$ $\mathrm{m} / \mathrm{s}$ pada detik ke 1,8

GAMBAR 5. Hasil simulasi pola aliran terhadap pengaruh waktu dengan $\mathrm{J}_{\mathrm{L}}=0,025 \mathrm{~m} / \mathrm{s}$ dan $\mathrm{J}_{\mathrm{G}}=0,05 \mathrm{~m} / \mathrm{s}$ 
Simulasi dengan $\mathrm{J}_{\mathrm{L}}=0,025 \mathrm{~m} / \mathrm{s}$ ketika diambil data pada tiap $0,3 \mathrm{~s}$ menunjukkan pola stratified dengan kecepatan rendah sampai kecepatan tinggi. Jika dilihat ketika pengambilan data pada detik ke 1,8 pola aliran sudah memenuhi pipa sehingga udara berangsur menuju tengah pipa. Hampir semua pola yang dihasilkan bergelombang.

\section{Pengaruh Kecepatan Superfisial Udara (JG) Terhadap $J L=0,05 \mathrm{~m} / \mathrm{s}$}

Variasi kedua adalah menggunakan $\mathrm{J}_{\mathrm{G}}=0,05$ $\mathrm{m} / \mathrm{s}, 0,1 \mathrm{~m} / \mathrm{s}, 0,5 \mathrm{~m} / \mathrm{s}$ dan $1 \mathrm{~m} / \mathrm{s}$ terhadap $\mathrm{J}_{\mathrm{L}}=$ $0,05 \mathrm{~m} / \mathrm{s}$ menghasilkan simulasi pola aliran terlihat pada gambar 6 .

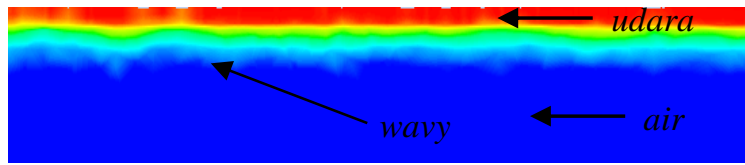

a) Pola aliran air-udara dengan $\mathrm{J}_{\mathrm{G}}=0,05$ $\mathrm{m} / \mathrm{s}$ dan

$$
\mathrm{J}_{\mathrm{L}}=0,05 \mathrm{~m} / \mathrm{s}
$$

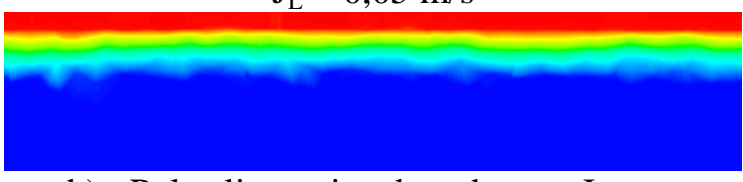

b) Pola aliran air-udara dengan $\mathrm{J}_{\mathrm{G}}=$ $0,1 \mathrm{~m} / \mathrm{dan}$

$\mathrm{J}_{\mathrm{L}}=0,05 \mathrm{~m} / \mathrm{s}$

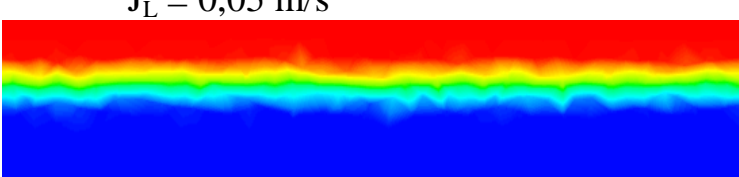

c) Pola aliran air-udara dengan $\mathrm{J}_{\mathrm{G}}=0,5$ $\mathrm{m} / \mathrm{s}$ dan $\mathrm{J}_{\mathrm{L}}=0,05 \mathrm{~m} / \mathrm{s}$

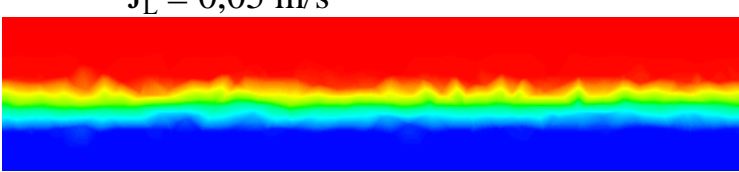

d) Pola aliran air-udara dengan $J_{G}=1 \mathrm{~m} / \mathrm{s}$ dan

$\mathrm{J}_{\mathrm{L}}=0,05 \mathrm{~m} / \mathrm{s}$

GAMBAR 6. Hasil simulasi pola aliran terhadap pengaruh kecepatan superfisial udara $\left(\mathrm{J}_{\mathrm{G}}\right)$ terhadap $\mathrm{J}_{\mathrm{L}}=0,05 \mathrm{~m} / \mathrm{s}$

Simulasi dengan $\mathrm{J}_{\mathrm{L}}=0,05 \mathrm{~m} / \mathrm{s}$ menunjukkan bahwa telah terjadi sebuah pola aliran stratified. Ketika kecepatan superfisial udara dinaikkan, maka permukaan air dan udara mengalami gelombang yang mempunyai amplitudo kecil dan panjang gelombang pendek serta teratur. Persentase antara air dan udara begitu jelas terlihat ketika kecepatan udara dengan $\mathrm{J}_{\mathrm{G}}=0,05$ $\mathrm{m} / \mathrm{s}$ pola yang dihasilkan udara berada di atas permukaan pipa dikarenakan amplitudo udara yang masuk berjalan lambat. Sedangkan ketika kecepatan $\mathrm{J}_{\mathrm{G}}$ dinaikkan mencapai $0,05 \mathrm{~m} / \mathrm{s}$ pola yang dihasilkan wavy.

\section{Pengaruh Waktu Terhadap Kecepatan} Superfisial Udara $(J G)$ dengan $J L=0,05 \mathrm{~m} / \mathrm{s}$

Variasi kedua adalah menggunakan $\mathrm{J}_{\mathrm{G}}=0,05$ $\mathrm{m} / \mathrm{s}$ dan $\mathrm{J}_{\mathrm{L}}=0,05 \mathrm{~m} / \mathrm{s}$ menghasilkan simulasi pola aliran terlihat pada gambar 7 .

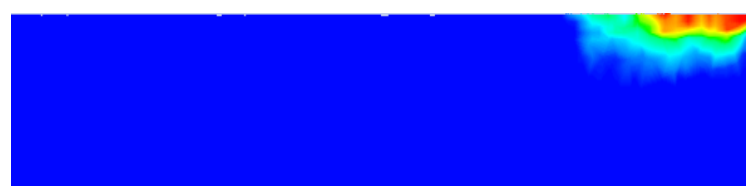

a) Pola aliran air-udara dengan $\mathrm{J}_{\mathrm{G}}=0,05$ $\mathrm{m} / \mathrm{s}$ pada detik ke 0,3

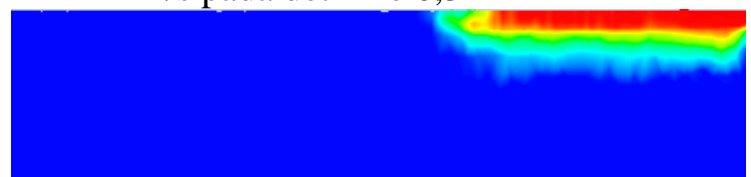

b) Pola aliran air-udara dengan $\mathrm{J}_{\mathrm{G}}=0,05$ $\mathrm{m} / \mathrm{s}$ pada detik ke 0,6

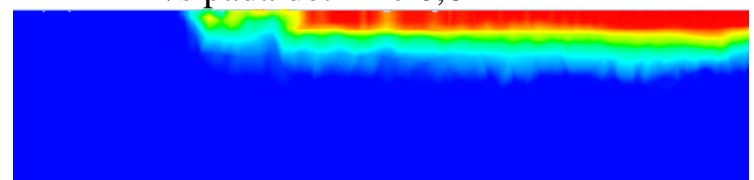

c) Pola aliran air-udara dengan $\mathrm{J}_{\mathrm{G}}=0,05$ $\mathrm{m} / \mathrm{s}$ pada detik ke 0,9

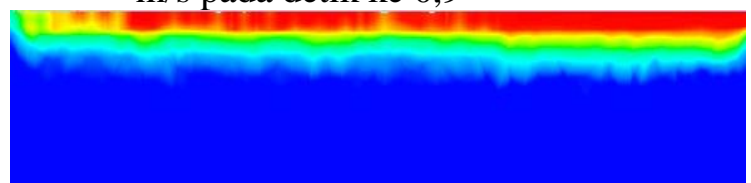

d) Pola aliran air-udara dengan $\mathrm{J}_{\mathrm{G}}=0,05$ $\mathrm{m} / \mathrm{s}$ pada detik ke 1,2

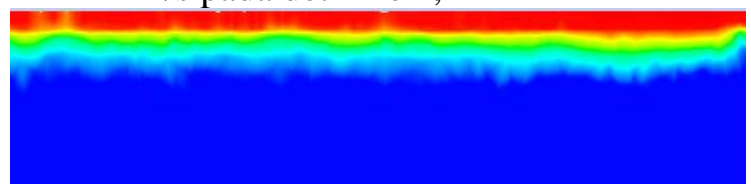

e) Pola aliran air-udara dengan $J_{G}=0,05$ $\mathrm{m} / \mathrm{s}$ pada detik ke 1,5

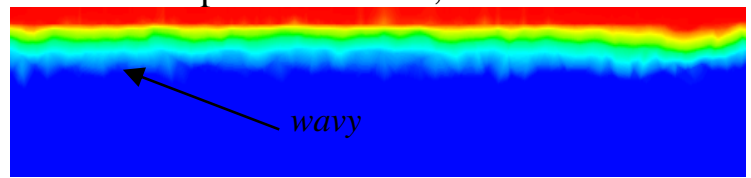

f) Pola aliran air-udara dengan $\mathrm{J}_{\mathrm{G}}=0,05$ $\mathrm{m} / \mathrm{s}$ pada detik ke $1,8 \mathrm{~s}$

GAMBAR 7. Hasil simulasi pola aliran terhadap pengaruh waktu dengan $\mathrm{J}_{\mathrm{G}}=0,05 \mathrm{~m} / \mathrm{s}$ dengan $\mathrm{J}_{\mathrm{L}}=0,05 \mathrm{~m} / \mathrm{s}$

Simulasi dengan $\mathrm{J}_{\mathrm{L}}=0,05 \mathrm{~m} / \mathrm{s}$ ketika diambil data tiap $0,3 \mathrm{~s}$, menunjukkan pola aliran berangsur memasuki ruang pipa. Ketika pengambilan data pada detik ke 1,5 terjadi pola aliran wavy dikarenakan udara mulai memasuki 
ujung pipa, yang mengakibatkan pola bergelombang. Ketika pola aliran memenuhi ruang pipa pola yang dihasilkan bergelombang namun beraturan. Semakin lama waktu pengambilan data, maka semakin teratur pola yang dihasilkannya

\section{Pengaruh Kecepatan Superfisial Udara (JG) Terhadap $J L=0,075 \mathrm{~m} / \mathrm{s}$}

Variasi ketiga adalah menggunakan $\mathrm{J}_{\mathrm{G}}=0,05$ $\mathrm{m} / \mathrm{s}, 0,1 \mathrm{~m} / \mathrm{s}, 0,5 \mathrm{~m} / \mathrm{s}$ dan $1 \mathrm{~m} / \mathrm{s}$ terhadap $\mathrm{J}_{\mathrm{L}}=$ $0,075 \mathrm{~m} / \mathrm{s}$ menghasilkan simulasi pola aliran terlihat pada gambar 8 .

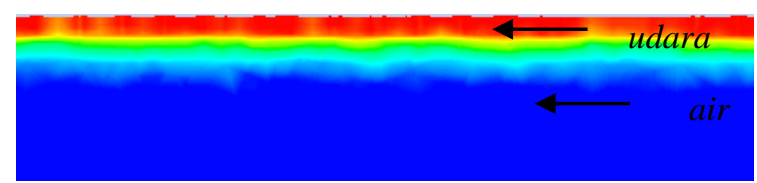

a) Pola aliran air-udara dengan $\mathrm{J}_{\mathrm{G}}=0,05$ $\mathrm{m} / \mathrm{s}$ dan $\mathrm{J}_{\mathrm{L}}=0,075 \mathrm{~m} / \mathrm{s}$

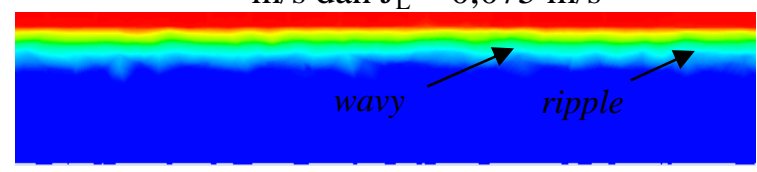

b) Pola aliran air-udara dengan $\mathrm{J}_{\mathrm{G}}=0,1$ $\mathrm{m} / \mathrm{s}$ dan $\mathrm{J}_{\mathrm{L}}=0,075 \mathrm{~m} / \mathrm{s}$

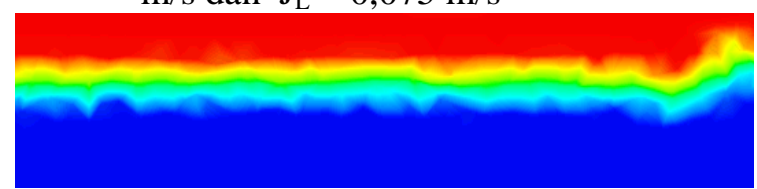

c) Pola aliran air-udara dengan $\mathrm{J}_{\mathrm{G}}=0,5$ $\mathrm{m} / \mathrm{s}$ dan $\mathrm{J}_{\mathrm{L}}=0,075 \mathrm{~m} / \mathrm{s}$

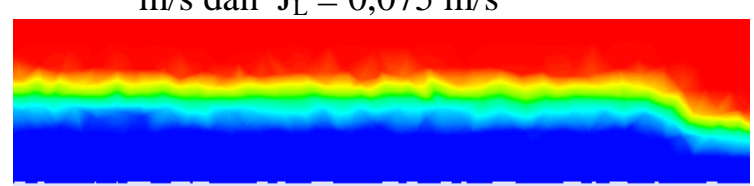

d) Pola aliran air-udara dengan $\mathrm{J}_{\mathrm{G}}=1$ $\mathrm{m} / \mathrm{s}$ dan $\mathrm{J}_{\mathrm{L}}=0,075 \mathrm{~m} / \mathrm{s}$

GAMBAR 8. Hasil simulasi pola aliran terhadap pengaruh kecepatan superfisial udara $\left(\mathrm{J}_{\mathrm{G}}\right)$ terhadap $\mathrm{J}_{\mathrm{L}}=0,075 \mathrm{~m} / \mathrm{s}$

Simulasi dengan $\mathrm{J}_{\mathrm{L}}=0,075 \mathrm{~m} / \mathrm{s}$ menunjukkan bahwa telah terjadi sebuah pola aliran stratified. Ketika kecepatan superfisial udara dinaikkan, maka permukaan air dan udara mengalami gelombang yang mempunyai amplitudo kecil dan panjang gelombang pendek serta teratur. Sedangkan ketika kecepatan $J_{G}$ dinaikkan mencapai $0,1 \mathrm{~m} / \mathrm{s}$ pola yang dihasilkan wavy + ripple. yaitu pola aliran wavy yang memanjang namun polanya sedikit berubah menjadi riakriak gelombang (ripple). Sampai ujung pipa pun pola yang dihasilkan bergelombang.

\section{Pengaruh Waktu Terhadap Kecepatan} Superfisial Udara $(J G)$ dengan $J L=0,075 \mathrm{~m} / \mathrm{s}$
Variasi ketiga adalah menggunakan $\mathrm{J}_{\mathrm{G}}=0,05$ $\mathrm{m} / \mathrm{s}$ dan $\mathrm{J}_{\mathrm{L}}=0,075 \mathrm{~m} / \mathrm{s}$ menghasilkan simulasi pola aliran terlihat pada Gambar 9.

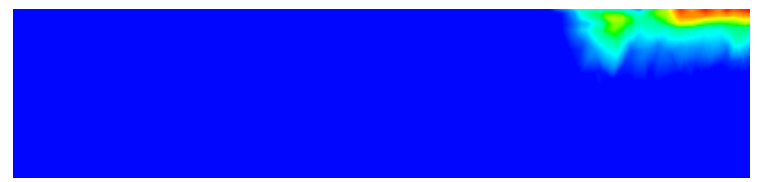

a) Pola aliran air-udara dengan $J_{G}=0,05$ $\mathrm{m} / \mathrm{s}$ pada detik ke 0,3

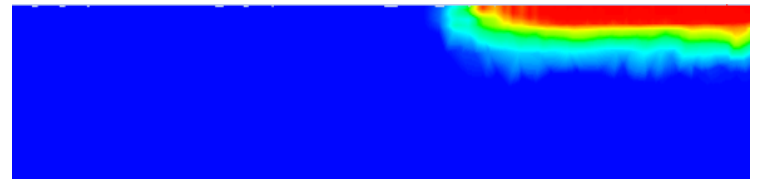

a) Pola aliran air-udara dengan $J_{G}=0,05$ $\mathrm{m} / \mathrm{s}$ pada detik ke 0,6

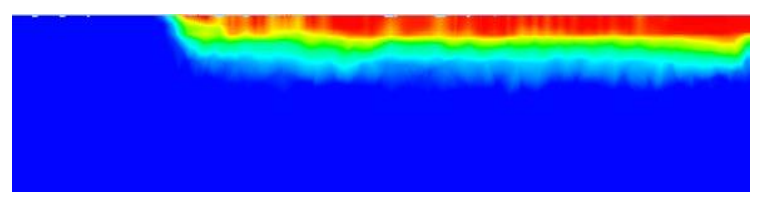

b) Pola aliran air-udara dengan $\mathrm{J}_{\mathrm{G}}=0,05$ $\mathrm{m} / \mathrm{s}$ pada detik ke 0,9

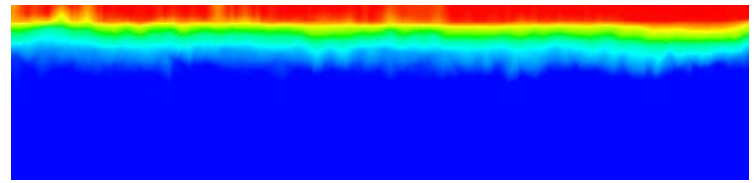

c) Pola aliran air-udara dengan $\mathrm{J}_{\mathrm{G}}=0,05$ $\mathrm{m} / \mathrm{s}$ pada detik ke 1,2

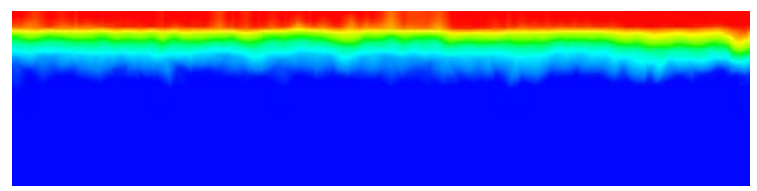

d) Pola aliran air-udara dengan $\mathrm{J}_{\mathrm{G}}=0,05$ $\mathrm{m} / \mathrm{s}$ pada detik ke 1,5

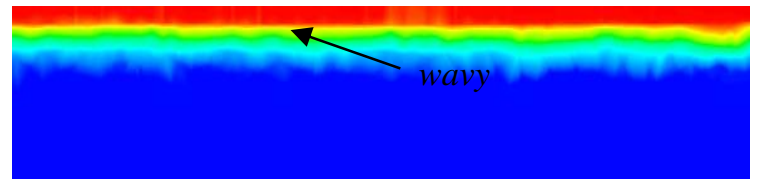

e) Pola aliran air-udara dengan $J_{G}=0,05$ $\mathrm{m} / \mathrm{s}$ pada detik ke 1,8

GAMBAR 9. Hasil simulasi pola aliran terhadap pengaruh waktu dengan $\mathrm{J}_{\mathrm{G}}=0,05 \mathrm{~m} / \mathrm{s}$ dan $\mathrm{J}_{\mathrm{L}}=0,075 \mathrm{~m} / \mathrm{s}$

Simulasi dengan $\mathrm{J}_{\mathrm{G}}=0,05 \mathrm{~m} / \mathrm{s}$ dan $\mathrm{J}_{\mathrm{L}}=0,075$ $\mathrm{m} / \mathrm{s}$ menghasilkan pola aliran stratified dengan kecepatan rendah, terlihat ketika pengambilan data pada detik ke 0,3 s, udara mulai memasiki ruang pipa dengan tekanan rendah berangsur masuk ruang pipa menuju ujung pipa. Seiring dengan penambahan waktu pengambilan data pola aliran berangsur bergelombang namun teratur Ketika detik ke 1,8 terjadi pola aliran wavy di ujung pipa. 


\section{Pengaruh Kecepatan Superfisial Udara (JG) Terhadap $J L=0,1 \mathrm{~m} / \mathrm{s}$}

Variasi keempat adalah menggunakan $\mathrm{J}_{\mathrm{G}}=0,05$ $\mathrm{m} / \mathrm{s}, 0,1 \mathrm{~m} / \mathrm{s}, 0,5 \mathrm{~m} / \mathrm{s}$ dan $1 \mathrm{~m} / \mathrm{s}$ terhadap $J_{\mathrm{L}}=$ $0,1 \mathrm{~m} / \mathrm{s}$ menghasilkan simulasi pola aliran terlihat pada Gambar 10.

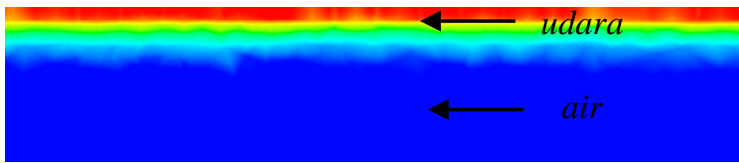

a) Pola aliran air-udara dengan $\mathrm{J}_{\mathrm{G}}=0,05$ $\mathrm{m} / \mathrm{s}$ dan $J_{\mathrm{L}}=0,1 \mathrm{~m} / \mathrm{s}$

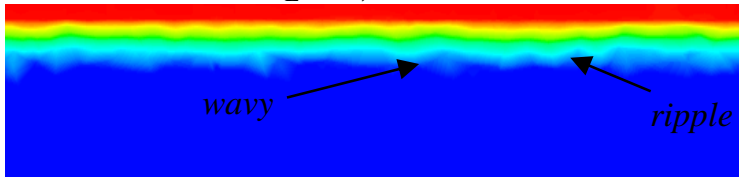

b) Pola aliran air-udara dengan $\mathrm{J}_{\mathrm{G}}=0,1$ $\mathrm{m} / \mathrm{s}$ dan $\mathrm{J}_{\mathrm{L}}=0,1 \mathrm{~m} / \mathrm{s}$

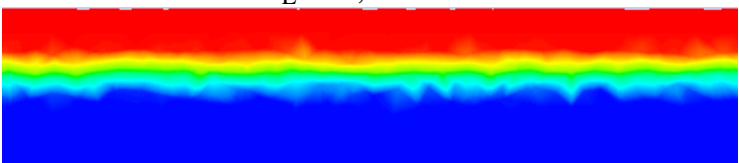

c) Pola aliran air-udara dengan $\mathrm{J}_{\mathrm{G}}=0,5$ $\mathrm{m} / \mathrm{s}$ dan $\mathrm{J}_{\mathrm{L}}=0,1 \mathrm{~m} / \mathrm{s}$

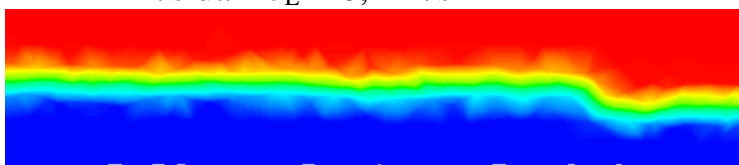

d) Pola aliran air-udara dengan $J_{G}=1 \mathrm{~m} / \mathrm{s}$ dan $\mathrm{J}_{\mathrm{L}}=0,1 \mathrm{~m} / \mathrm{s}$

GAMBAR 10. Hasil simulasi pola aliran terhadap pengaruh kecepatan superfisia udara $\left(\mathrm{J}_{\mathrm{G}}\right)$ terhadap $\mathrm{J}_{\mathrm{L}}=0,1 \mathrm{~m} / \mathrm{s}$

Simulasi dengan $\mathrm{J}_{\mathrm{L}}=0,1 \mathrm{~m} / \mathrm{s}$. Ketika kecepatan superfisial air meningkat pola yang dihasilkan membentuk riak-riak gelombang (ripple), akan membentuk pola gelomabang panjang sehingga menunjukkan pola wavy + ripple. Hal ini terjadi ketika penambahan kecepatan superfisial air dan superfisial udara yaitu aliran wavy yang memanjang namun berbentuk riak-riak gelombang.

\section{Pengaruh Waktu Terhadap Kecepatan} Superfisial Udara ( JG) dengan $J L=0,1 \mathrm{~m} / \mathrm{s}$

Variasi keempat adalah menggunakan $\mathrm{J}_{\mathrm{G}}=0,05$ $\mathrm{m} / \mathrm{s}$ dan $\mathrm{J}_{\mathrm{L}}=0,1 \mathrm{~m} / \mathrm{s}$ menghasilkan simulasi pola aliran terlihat pada gambar 11 .

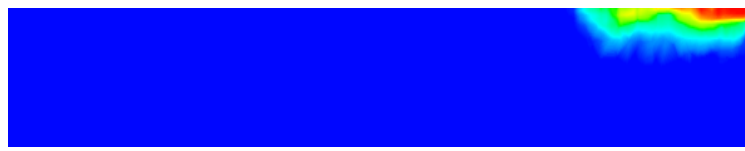

a) Pola aliran air-udara dengan $J_{G}=0,05$ $\mathrm{m} / \mathrm{s}$ pada detik ke 0,3

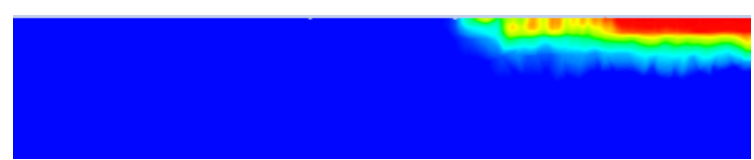

b) Pola aliran air-udara dengan $\mathrm{J}_{\mathrm{G}}=0,05$ $\mathrm{m} / \mathrm{s}$ pada detik ke 0,6

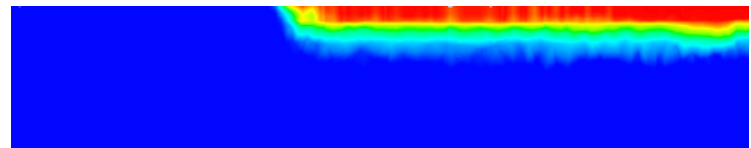

c) Pola aliran air-udara dengan $\mathrm{J}_{\mathrm{G}}=0,05$ $\mathrm{m} / \mathrm{s}$ pada detik ke 0,9

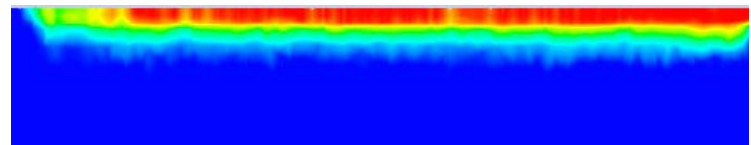

d) Pola aliran air-udara dengan $\mathrm{J}_{\mathrm{G}}=0,05$ $\mathrm{m} / \mathrm{s}$ pada detik ke 1,2

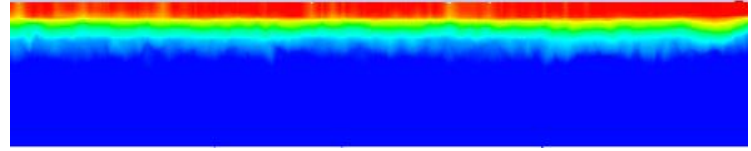

e) Pola aliran air-udara dengan $J_{G}=0,05$ $\mathrm{m} / \mathrm{s}$ pada detik ke 1,5

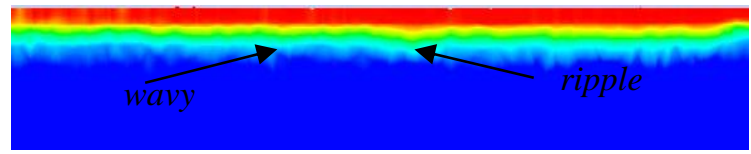

f) Pola aliran air-udara dengan $J_{G}=0,05$ $\mathrm{m} / \mathrm{s}$ pada detik ke 1,8

GAMBAR 11. Hasil simulasi pola aliran terhadap pengaruh waktu dengan $\mathrm{J}_{\mathrm{G}}=0,05 \mathrm{~m} / \mathrm{s}$ dan $\mathrm{J}_{\mathrm{L}}=0,1 \mathrm{~m} / \mathrm{s}$

Simulasi dengan $J_{L}=0,1 \mathrm{~m} / \mathrm{s}$ dan $J_{G}=0,05 \mathrm{~m} / \mathrm{s}$. Pola aliran terlihat berangsur memasuki ruang pipa dengan kecepatan lambat. Ketika kecepatan superfisial air meningkat pola yang dihasilkan membentuk riak-riak gelombang (ripple), akan membentuk pola gelomabang panjang sehingga menunjukkan pola wavy + ripple pada detik ke 1,8. Terlihat waktu pengambilan data semakin lama maka pola yang dihasilkan semakin teratur, walaupun hampir pola membentuk gelombang. Sementara itu, (Sampaio, Faccini, Transfer, \& 2008, n.d.) menyatakan bahwa munculnya komputer berkecepatan tinggi baru-baru ini dan pengembangan model turbulensi canggih, teknik fluida gabungan (CFD) teknik telah diterapkan untuk simulasi aliran dua-fase gascair bertingkat. Shoham dan Taitel (1988) menyajikan salah satu solusi numerik dua dimensi awal dari aliran gas-cair turbulen yang sepenuhnya dikembangkan dalam pipa horisontal dan miring. Fase gas diperlakukan sebagai aliran massal, sedangkan persamaan fase fasa cair dalam sistem koordinat bipolar 
dengan model aljabar turbulen diselesaikan dengan menggunakan metode beda hingga. Juga menggunakan sistem koordinat bipolar, Issa (1988) memodelkan aliran bertingkat, dengan permukaan antarmuka yang halus, tetapi memecahkan persamaan momentum aksial di kedua fase gas dan cair dengan model k-e standar. Fungsi dinding digunakan dalam batas-batas yang kuat. Hasil untuk aliran dalam pipa diameter 25,4 mm cukup sesuai dengan prediksi yang diberikan oleh model mekanistik

\section{KESIMPULAN}

Berdasarkan hasil simulasi dan pembahasan yang telah dilakukan pada bab sebelumnya, dapat disimpulkan bahwa :

1. Aliran Stratified terjadi dikarenakan kecepatan rendah dari fase cairan dan gas terjadi sangat jelas, dalam simulasi ini air dan udara terpisah dengan jelas.

2. Pola aliran tidak konstan atau berubah ubah bentuk tergantung dari kecepatan superfisial gas atau udara dan kecepatan superfisial air serta waktu dalam pengambilan data. Semakin lama waktu yang diambil maka aliran akan menghasilkan pola aliran stratified yang sempurna.

3. Kenaikan nilai $\mathrm{J}_{\mathrm{G}}$ akan menyebabkan tingginya gelombang dan akan mengakibatkan bertambah terjadinya pola aliran stratified wavy+ripple

4. Frekuensi gelombang stratified wavy dan ripple akan cenderung turun jika nilai $\mathrm{J}_{\mathrm{L}}$ semakin membesar, sedangkan pengaruh $\mathrm{J}_{\mathrm{G}}$ tidaklah signifikan terhadap frekuensi gelombang.

\section{DAFTAR PUSTAKA}

Abbasi, Mohammad and Zahra. B. (2014). Analytical Simulation Of Flow and Heat Transfer of Two-Phase Nanofluid (Stratified Flow Regime), International Journal of Chemical Engineering, 1 :7.

Desamala, Anand. B., Anjali D., Vinayak V., Bharath K. G., Ashok K. D., Tapas K. M. (2013). CFD Simulation and Validation of Flow Pattern Transition Boundaries during Moderately Viscous Oil-Water Two-Phase Flow through Horizontal Pipeline. Journal of World Academy of
Science, Engineering and Technology, pp. 1150-1155.

Gunawan, D., Akhmad Z. H., Indarto. (2015). Studi Eksperimen Mengenai Fluktuasi Tekanan Dan Tegangan Geser Antar Muka Pada Aliran Stratified Air-Udara Pada Pipa Horizontal". Vol. 10, No. 1, pp. 32-40.

Hudaya, A. Z., Indarto., Deendarlianto. (2013). Penentuan Sub-sub Daerah Aliran Stratified Udara-Air pada Pipa Horisontal Menggunakan Constant Electric Current method (CECM)". Jurnal Simetris. Vol. 14, No. 1, pp. 49-57.

Korawan, Agus. D., (2015). Pola Aliran Dua Fase (Air-Udara) Pada Pipa Horisontal Dengan Variasi Kecepatan Superfisial Air. Jurnal Mekanika. Vol. 14, No. 1, pp. 57-63.

Mazumder, Quamrul. H., (2012). CFD Analysis of Single and Multiphase Flow Characteristics in Elbow. Jurnal of Scientific Research, Engineering, Vol. 4, pp. 210-214.

O.Shoham, Y. Taitel, Stratified turbulentturbulent gas-liquid flow in horizontal and inclined pipes, AIChE J. 30 (1984) 377-385.

R.Issa, (1988). Prediction of turbulent, stratified, two-phase flow in inclined pipes and channel, Int. J. Multiphase Flow 14 141-154

Sampaio, P. de, Faccini, J., Transfer, J. S.-J. of H. and M., \& 2008, undefined. (n.d.). Modelling of stratified gas-liquid twophase flow in horizontal circular pipes. Elsevier. Retrieved from https://www.sciencedirect.com/science/ar ticle/pii/S0017931007006126

Santoso, B., Fitroh D. R., Indarto, Deendarlianto, Thomas S. W., (2012). Fluktuasi Beda Tekanan Dari Pola Aliran Slug Air-Udara Pada Aliran Dua Fase Searah Pipa Horizontal. Jurnal Teknik Mesin Rotasi. Vol. 14, No. 2, pp. 1-6.

Sukamta, Indarto, Purnomo, Tri A. R. (2010). Identifikasi Pola Aliran Dua Fasa UapKondensat berdasarkan Pengukuran Beda Tekanan Pada Pipa Horisontal. Jurnal Ilmiah Semesta Teknika. Vol. 13, No. 1, pp. 83-94. 
Terzuoli F., M. C. Galassi., D. Mazzini., F. D' Auria. (2008). CFD Code Validation Against Stratified Air-Water Flow Experimental Data. Hindawi Publishing Corporation Science and Technology Of Nuclear Installations. pp. 1- 7.

PENUlis:

Sukamta

Program Studi Teknik Mesin, Fakultas Teknik, Universitas Muhammadiyah Yogyakarta, Bantul, D.I. Yogyakarta.

Email: sukamta@umy.ac.id
Thoharudin

Program Studi Teknik Mesin, Fakultas Teknik, Universitas Muhammadiyah Yogyakarta, Bantul, D.I. Yogyakarta.

Email: thoharudin@gmail.com

Dedy Meilanto Nugroho

Program Studi Teknik Mesin, Fakultas Teknik, Universitas Muhammadiyah Yogyakarta, Bantul, D.I. Yogyakarta.

Email: dedy.meilanto.2012@umy.ac.id 